\title{
HUBUNGAN KEMAMPUAN MENGGUNAKAN TEKNOLOGI KEPERAWATAN DENGAN CARING MAHASISWA PROFESI NERS DI SEKOLAH TINGGI ILMU KESEHATAN WILAYAH SURABAYA
}

\section{The Relationship Between Technological Skill Competency and Caring of Nursing Profession Students in Surabaya Region}

\section{Riwayat artikel \\ Diajukan:}

11 September 2020

Diterima:

25 September 2020

Penulis Korespondensi:

- Ignata Yuliati

STIKES Katolik St.

Vincentius a Paulo

Surabaya

ignatayuli@gmail.com

\section{Kata Kunci:}

Teknologi keperawatan, Caring, TCCNI-IV, TSCNI

\author{
Ignata Yuliati, Marcellina Rasemi Widayanti \\ STIKES Katolik St. Vincentius a Paulo Surabaya
}

\begin{abstract}
Abstrak
Pendahuluan: Teknologi merupakan kehadiran yang terintegrasi antara ilmu pengetahuan dan mesin. Teknologi informasi dalam keperawatan meliputi pengetahuan, sikap dan ketrampilan. Ketiga hal ini dibutuhkan oleh seorang tenaga kesehatan dalam menjalankan profesinya. Kemampuan perawat menggunakan teknologi keperawatan merupakan bentuk kepedulian/ caring didalam keperawatan. Perilaku caring perawat sangat penting dalam memenuhi kepuasan pasien, oleh karena itu pemahaman mahasiswa tentang technologi sebagai bentuk caring perawat perlu ditanamkan sejak masa pendidikan. Tujuan: Mengidentifikasi hubungan kemampuan menggunakan teknologi keperawatan dan caring mahasiswa profesi Ners.. Metode: Analitik korelasi dengan pendekatan cross sectional. Subyek penelitian ini adalah mahasiswa profesi ners, dengan populasi penelitian seluruh mahasiswa profesi ners yang kuliah di STIKES wilayah Surabaya yaitu sebanyak 90 mahasiswa. Responden memenuhi kriteria inklusi yaitu kuliah di STIKes wilayah Surabaya, bersedia menjadi responden, dan lulus sarjana keperawatan (S. Kep) maksimal satu tahun sebelum melanjutkan pendidikan profesi ners. Pengumpulan data menggunakan kuesioner technological skill competency as caring in nursing instrumen (TSCNI) dan technological competency as caring in nursing instrument (TCCNI). Hasil: Hasil penelitian menunjukan ada hubungan yang signifikan antara kemampuan menggunakan teknologi (alat-alat kesehatan/medical devices) dengan caring mahasiswa profesi Ners $(\mathrm{p}=0.000 ; \mathrm{r}=0.630$. Ada hubungan signifikan antara kemampuan menggunakan teknologi (Informasi dan Teknologi Komunikasi/Information and communication technology) dengan caring mahasiswa profesi ners $(\mathrm{p}=0.000 ; \mathrm{r}=$ 0.469). Kesimpulan: Kemampuan menggunakan teknologi membuat perawat memahami pasien sebagai manusia yang utuh atau holistic. Jika perawat memahami pasien secara utuh maka dia akan memahami segala aspek dalam diri pasien sebagai pribadi yang unik, hal ini akan membantu pasien untuk berkembang dan mempercepat proses penyembuhan. Kemampuan perawat menggunakan teknologi adalah adalah ekspresi caring dalam keperawatan, yang mana caring dan teknologi sebagai satu kesatuan. Teknologi memegang peranan penting dalam perawatan kesehatan, teknologi digunakan untuk meningkatkan keamanan pasien, menyelamatkan jiwa pasien dan membantu perawat dalam pekerjaannya. Menanamkan caring sejak masa pendidikan sangat penting karena ini adalah tahap pertama mahasiswa belajar nilai dan makna dari profesi perawat.
\end{abstract}

\footnotetext{
Abstract

Background: Technology is an integrated presence between science and machines. Information technology in nursing includes knowledge, attitudes and skills. These three things are needed by a health care profession in their daily work. The ability of nurses to use nursing technology is a form of caring. Nurse caring behavior is very important in fulfilling patient satisfaction, therefore students' understanding of technology as a form of caring in nursing needs to be instilled since the period of education. Objective: The purpose of this study was to identify the relationship between the technological skill competency in nursing and caring of nursing profession students. Method The research method used in this study is correlation analytic with cross sectional approach. Questionnaire was utilized to gather the needed data and information. The subjects of this study were 90 nursing students, total sampling was applied to gained participants.
} 
Respondents met the inclusion criteria, namely studying at STIKes in the Surabaya region, being willing to be respondents, and graduating a bachelor's degree in nursing, a maximum of one year before continuing to Ners profession student. Results: The results showed that there was a significant relationship between the ability to use technology (medical devices) and caring of Ners professional students $(p=0.000 ; r=0.630$. There was a significant relationship between the ability to use technology (Information and Communication Technology) and caring ( $p=0.000 ; r=0.469)$. Conclusion: The ability to use technology makes nurses understand the patient as a whole or holistic human. If the nurse understands the patient completely then he will understand all aspects of the patient as a unique person, this will help patients to develop and accelerate the healing process. The ability of nurses to use technology is an expression of caring in nursing, where caring and technology are an integral part. Technology plays an important role in health care, technology is used to improve patient safety, save lives patient and support nurses in their job. Teaching caring from the time of education is very important because this is the first stage for nursing students to learn the value and meaning of the nursing profession.

\section{PENDAHULUAN}

Pada jaman sekarang ini, teknologi mendominasi semua bidang profesi termasuk profesi keperawatan. Teknologi mempengaruhi kualitas pelayanan seorang tenaga kesehatan terhadap individu atau masyarakat yang dilayaninya. Teknologi merupakan kehadiran yang terintegrasi antara ilmu pengetahuan dan mesin (Locsin, 2016). Teknologi informasi dalam keperawatan meliputi pengetahuan, sikap dan ketrampilan. Ketiga hal ini dibutuhkan oleh seorang tenaga kesehatan dalam menjalankan profesinya. Pada jaman generasi milenial internet dan teknologi mudah diakses, mahasiswa perawat saat ini sering disebut sebagai generasi millennial (Doswell et al., 2013). Mahasiswa perawat perlu dipersiapkan dalam penggunaan teknologi keperawatan karena akan sangat dibutuhkan dalam praktik keperawatan. Mahasiswa profesi Ners adalah calon-calon perawat yang akan memberikan pelayanan keperawatan secara komprehensif. Oleh karena itu masa pendidikan di program Ners adalah waktu yang tepat untuk membangun persepsi yang benar tentang teknologi keperawatan sebagai salah satu bentuk caring perwat. Juga sangat penting mengkaji kemampuan mahasiswa menggunakan teknologi keperawatan, perilaku caring yang dimiliki oleh mahasiswa profesi Ners dalam memberikan pelayanan keperawatan kepada pasien saat praktik klinik di lahan praktik. Teknologi keperawatan yang cepat berkembang dan tidak diikuti dengan kemampuan atau skill menggunakan peralatan medis yang semakin canggih, akan mempengaruhi caring mahasiswa dalam memberikan pelayanan kepada pasien. Penelitian terdahulu menunjukan tingkat kemampuan perawat menggunakan teknologi masih pada level cukup, demikian juga kemampuan perawat dalam menggunakan teknologi informasi dan komunikasi berada pada level cukup (Yuliati I, 2018). Hasil penelitian terdahulu menunjukan adanya hubungan antara perilaku caring mahasiswa perawat dengan lama masa studi (tingkat pendidikan) (Yuliati, Kusumaningsih and Novita, 2017). Membangun pemahaman bahwa penggunaan teknologi adalah bentuk caring pada mahasiswa dalam masa pendidikan merupakan salah satu tujuan yang sangat penting. Pemahaman ini sangat dipengaruhi oleh perilaku mahasiswa, program dan pengalaman tentang profesi (Gözütok Konuk and Tanyer, 2019). Tokoh keperawatan Florence Nightingale, perawat sudah belajar tentang konsep filosofi caring. Konsep ini kemudian dikembangkan oleh theorist keperawatan seperti teori Leinenger, Boykine dan Schoenhofer, Roach Watson.

\section{METODE}

Metode penelitian yang digunakan dalam penelitian ini adalah analitik korelasi dengan pendekatan cross sectional. Subyek penelitian ini adalah mahasiswa profesi ners, dengan populasi penelitian seluruh mahasiswa profesi ners yang kuliah di STIKES wilayah Surabaya yaitu sebanyak 90 mahasiswa. Responden memenuhi kriteria inklusi yaitu kuliah di STIKes wilayah Surabaya, bersedia menjadi responden, dan lulus sarjana keperawatan (S. Kep) maksimal satu tahun sebelum melanjutkan pendidikan profesi ners. Pengumpulan data menggunakan kuesioner technological skill competency as caring in nursing instrumen (TSCNI) dan technological competency as caring in nursing instrument (TCCNI). TSCNI mengukur kemampuan 
menggunakan alat-alat kesehatan (medical devices) kuesioner nomer $1,2,3,4,5,6,7,8,9,10,11,12,13,14,15,16,17,18,20$, $22,23,24,26,27,28,29$, dan 30, informasi dan teknologi komunikasi (Information communication tekchnology/ICT) kuesioner nomer

$19,21,25,31,32,33,34,35,36,37,38,39,40,41,42,4$

3,44 , dan 45. TCCNI_IV mengukur caring mahasiswa yakni kemampuan mengintegrasikan pemahaman terhadap teknologi sebagai bentuk caring (technological knowing and technological caring). Kuesioner menggunakan skala likert satu (1) sampai lima (5) yakni trainee, pemula, kompeten, cakap dan ahli. Peneliti memberikan penjelasan kepada penanggungjawab dari masing-masing STIKES (sesuai dengan SDM yang ditunjuk oleh ketua STIKES) tentang kuesioner diberikan kepada responden mahasiswa dan cara menjawab pertayaan melalui google form Uji Statistik yang digunakan untuk menganalisis korelasi adalah uji Rank Spearman. Penarikan kesimpulan hasil uji statistik ini adalah apabila nilai $\mathrm{p}<\alpha$ dengan derajat kemaknaan $\alpha=$ 0,05 maka ada hubungan antara antara kemampuan menggunakan teknologi keperawatan dengan caring mahasiswa profesi ners.

\section{HASIL}

Hasil penelitian pada table 1 menunjukan sebagian besar responden yaitu $90 \%$ dengan jenis kelamin perempuan.

Tabel 1 Distribusi Frekuensi dan Persentase Responden berdasarkan Jenis kelamin.

\begin{tabular}{lll}
\hline Jenis kelamin & Frekuensi & $\begin{array}{l}\text { Persentase } \\
(\mathbf{\%})\end{array}$ \\
\hline Laki-laki & 9 & 10.0 \\
Perempuan & 81 & 90.0 \\
Total & $\mathbf{9 0}$ & $\mathbf{1 0 0 \%}$ \\
\hline
\end{tabular}

Hasil penelitian menunjukan bahwa sebagian besar responden berada pada usia remaja akhir yaitu sebanyak $82.2 \%$. Berdasarkan Depkes RI, 2009, Usia Masa remaja akhir adalah rentang antara 17-25 tahun

Table 2. Distribusi Frekuensi dan Persentase Responden berdasarkan Usia

\begin{tabular}{lll}
\hline Klafikasi & Frekuensi & $\begin{array}{l}\text { Persentase } \\
(\boldsymbol{\%})\end{array}$ \\
\hline Remaja akhir & 74 & 82.2 \\
Dewasa awal & 11 & 12.2 \\
Dewasa akhir & 4 & 4.4 \\
\hline
\end{tabular}

\begin{tabular}{lll}
\hline Lansia awal & 1 & 1.1 \\
Total & $\mathbf{9 0}$ & $\mathbf{1 0 0 \%}$ \\
\hline
\end{tabular}

Hasil pada penelitian menunjukan bahwa sebagian besar responden berasal dari program regular yaitu sebanyak $74.4 \%$.

Table 3. Distribusi Frekuensi dan Persentase Responden berdasarkan Pendidikan

\begin{tabular}{lll}
\hline Klasifikasi & Frekuensi & $\begin{array}{l}\text { Persentase } \\
(\%)\end{array}$ \\
\hline Alih jenjang & 23 & 25.6 \\
Regular & 67 & 74.4 \\
Total & 90 & $100 \%$ \\
\hline
\end{tabular}

Hasil penelitian menunjukan bahwa responden menyatakan diri "cakap" dalam menggunakan alat kesehatan (medical devices) berdarsarkan pada tujuh pernyataan berikut: Saya mampu mengukur tekanan darah pasien dengan menggunakan tensimeter manual atau elektrik (mean 3.67); Saya mampu menginterpretasikan hasil pemeriksaan tekanan darah pasien (mean 3.52); Saya mampu menyimpan tensimeter dengan cara yang benar (mengembalikan air raksa pada posisi nol)(mean 3.74); Saya mampu mengkaji suhu tubuh pasien dengan menggunakan termometer elektronik dan mengerti makna dari hasil pemeriksaan (mean 3.79); Saya mampu menggunakan remote air condition (AC) untuk memberikan lingkungan yang nyaman pada pasien (mean 3.70); Saya mampu mencari informasi tentang kesehatan secara online (3.51); Saya mampu memasang folley catheter pada pasien (mean 2.98).

Sebaliknya responden menyatakan diri masih pemula dalam hal: Saya mengetahui bahwa teknologi termasuk pengelolaan alat tenun (mean 2.18); Saya mampu menggunakan wireless sebagai sarana komunikasi dengan tim medis yang lain (mean 2.33); dan Saya mampu mengobservasi pasien yang menggunakan tracheostomy, stoma, dll (mean 2.49).

Table 4. Kemampuan menggunakan Teknologi Alatalat Kesehatan (Medical Devices)

\begin{tabular}{cc}
\hline Pernyataan & Mean Stand. Interp \\
Dev \\
(SD)
\end{tabular}


\begin{tabular}{llll}
\hline Saya mampu memberikan & 3.37 & 0.95 & Kompeten
\end{tabular} nebulezer pada pasien dengan masalah pada sistem pernafasan

\begin{tabular}{llll}
\hline Saya mampu mengakses & 3.32 & 1.01 & Kompeten
\end{tabular} sumber informasi

kesehatan melalui media

elektronik

\section{Keterangan}

1.00-1.50 Trainee

1.51-2.50 Pemula

2.51-3.50 Kompeten

3.51-4.50 Cakap

4.51-5.00 Ahli

Hasil penelitian menunjukan bahwa responden menyatakan diri "cakap" dalam menggunakan informasi dan teknologi komunikasi berdasarkan pernyataan berikut: Saya mampu menggunakan email sebagai sarana komunikasi (mean 3.62); Saya mampu mengakses internet dan world wide web (3.51).

Table 5. Kemampuan Menggunakan Informasi dan Teknologi Komunikasi

\begin{tabular}{llll}
\hline Pernyataan & $\begin{array}{l}\text { Mea } \\
\text { n }\end{array}$ & $\begin{array}{l}\text { Stand. Interp } \\
\text { Dev } \\
\text { (SD) }\end{array}$ & \\
\hline $\begin{array}{l}\text { Saya mampu } \\
\text { menginterpretasikan hasil }\end{array}$ & 2.00 & 1.01 & Pemula \\
$\begin{array}{l}\text { ECG dan mengerti makna } \\
\text { dari hasil pemeriksaan }\end{array}$ & & & \\
\end{tabular}

\begin{tabular}{lllll}
\hline Saya & mampu & 2.66 & 1.18 & Kompe
\end{tabular}

mendokumentasikan data ten

pasien pada komputer atau

laptop

\begin{tabular}{llll}
\hline $\begin{array}{l}\text { Saya mampu } \\
\text { menggunakan }\end{array}$ & 2.13 & 1.08 & Pemula \\
& & &
\end{tabular}

sorfware, berupa

handheld dalam

melakukan

asuhan

keperawatan

\begin{tabular}{lrlll}
\hline $\begin{array}{l}\text { Saya mengetahui etika } \\
\text { dalam sistem informasi } \\
\text { teknologi yang harus saya } \\
\text { patuhi }\end{array}$ & & 0.98 & $\begin{array}{c}\text { Kompe } \\
\text { ten }\end{array}$ \\
\hline $\begin{array}{l}\text { Saya rampu } \\
\text { menggunakan }\end{array}$ & $\begin{array}{r}\text { email } \\
\text { sebagai }\end{array}$ & & & \\
komunikasi & sarana & & & \\
\hline
\end{tabular}

\begin{tabular}{llll}
\hline Saya mampu mengakses 3.51 & 1.10 & Cakap \\
internet dan world wide web & & & \\
\hline Saya mampu & 2.40 & 1.17 & Pemula \\
menggunakan Handheld & & & \\
computer untuk & & & \\
mendokumentasikan & & & \\
pengkajian atau asuhan & & & \\
keperawatan
\end{tabular}

\begin{tabular}{lllll}
\hline Saya mampu & 2.44 & 1.24 & Pemula \\
menggunakan alat & & & \\
komunikasi digital untuk & & & \\
koordinasi terapi dan & & & \\
tindakan pada pasien & & & \\
dengan dokter dan & & & \\
profesional kesehatan lain & & &
\end{tabular}

\begin{tabular}{llll}
\hline Saya mampu menilai klinis & 2.53 & 1.16 & Kompe
\end{tabular} pasien menggunakan sistem

skoring dengan aplikasi

seperti

EWS(early warning system)

\begin{tabular}{llll}
\hline Saya mampu & 2.23 & 1.14 & Pemula \\
menggunakan & & & \\
fasilitas pelaporan & & & \\
hasil pemeriksaan, & & & \\
pemantauan hasil & & & \\
mutu, pelaporan & & & \\
insiden keselamatan & & & \\
pasien secara online & & &
\end{tabular}

\begin{tabular}{llll}
\hline $\begin{array}{l}\text { Saya mampu menggunakan } \\
\text { sistem } 2.00\end{array}$ & 1.04 & Pemula \\
managemen \\
informasi rumah sakit \\
(SIMRS)
\end{tabular}

\begin{tabular}{|c|c|c|}
\hline $\begin{array}{l}\text { Saya mengerti akses pintu } 2.28 \\
\text { masuk ruangan khusus } \\
\text { menggunakan sidik jari } \\
\text { seperti ruangan } \\
\text { Farmasi, NICU, Rekam } \\
\text { medis yang hanya bisa } \\
\text { diakses oleh petugas } \\
\text { ruangan tersebut }\end{array}$ & 1.19 & $\begin{array}{l}\text { Kompe } \\
\text { ten }\end{array}$ \\
\hline $\begin{array}{lcc}\text { aya } & \text { mampu } & 2.33 \\
\text { enggunakan } & \text { Absensi } & \\
\text { nas dengan finger skrin } & \end{array}$ & 1.18 & Pemula \\
\hline
\end{tabular}




\begin{tabular}{lllll}
\hline Saya & mampu & 2.08 & 1.19 & Pemula
\end{tabular}

menerapkan peresepan

semua obat baik biasa

atau CITO dengan scan

langsung ke Farmasi

\begin{tabular}{lrlll}
\hline $\begin{array}{l}\text { Saya mampu } \\
\text { informasi }\end{array}$ & $\begin{array}{r}\text { meminta } \\
\text { hasil }\end{array}$ & 2.13 & 1.25 & Pemula \\
pemeriksaan & & & & \\
laboratorium & pasien & & & \\
melalui akses online via & & & \\
computer ruangan tanpa & & & \\
harus telepon ke ruang & & & \\
laboratorium & & & &
\end{tabular}

\begin{tabular}{lllll}
\hline Saya mampu melakukan & 2.33 & 1.21 & Pemula
\end{tabular}

pelaporan hasil pemeriksaan

atau keadaan umum pasien

via

WhatsApp dengan HP

khusus ruangan

\begin{tabular}{|c|c|}
\hline $\begin{array}{l}\text { Saya mampu memperoleh } \\
\text { Data dan informasi ilmu } \\
\text { yang up to date via E- } \\
\text { learnin } \\
\text { g rumah sakit }\end{array}$ & $2.16 \quad 1.10$ \\
\hline
\end{tabular}

Hasil penelitian menunjukan caring responden, responden menyatakan memiliki tingkat caring "cakap" pada pernyataan berikut: Keperawatan adalah bidang unik dari ilmu pengetahuan ketrampilan dan kemampuan untuk merawat (3.52); Sikap peduli dalam keperawatan adalah mau mendengarkan pasien, bekerjasama dengan pasien, dan berada bersama pasien (3.56); Perawat menjalin hubungan dengan pasiennya dalam rangka menciptakan suasana aman dan nyaman (3.51).

Table 6. Kemampuan Caring Mahasiswa Profesi Ners

\begin{tabular}{llll}
\hline Pernyataan & $\begin{array}{c}\text { Mean Stand. Inter } \\
\text { Dev } \\
\text { (SD) }\end{array}$ & \\
\hline $\begin{array}{l}\text { Keperawatan sebagai } \\
\text { bagian penting dalam } \\
\text { pelayanan kesehatan, }\end{array}$ & 3.26 & 1.04 & Kompeten \\
$\begin{array}{l}\text { yang berfokus pada } \\
\text { pelayanan manusia }\end{array}$ & & & \\
\end{tabular}

$\begin{array}{lllll}\text { Tehnologi membantu para3.07 } & 1.10 & \text { Kompeten }\end{array}$ perawat untuk mengetahui

"siapa" dan "apa' dari setiap

\begin{tabular}{llll}
\hline Tujuan akhir dari tindakan & 3.41 & 1.08 & Kompeten
\end{tabular} keperawatan adalah penyembuhan,

menyelamatkan kehidupan,

dan meningkatkan

kemandirian \begin{tabular}{lllll}
\hline Perawat menggunakan cara-3.49 & 1.06 & Kompeten
\end{tabular} cara yang unik dalam melayani

pasien

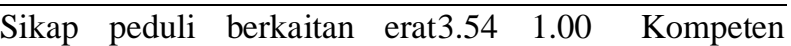
dengan belas kasih, kehadiran

secara fisik, rasa nyaman, dan penghargaan pribadi secara

utuh.

\begin{tabular}{llllll}
\hline Teknologi & dan & sikap & 3.47 & 0.98 & Kompeten
\end{tabular} peduli membantu untuk menumbuhkan harga diri ketika digunakan dengan tepat

Mengetahui "apa" dan "siapa"3.38 1.12 Kompeten tentang pasien sama dengan menghargai pasien bukan hanya

sekedar penampilan secara

fisiknya saja

\begin{tabular}{lllll}
\hline Keperawatan & adalah & 3.52 & 1.00 & Cakap
\end{tabular}

bidang unik dari ilmu

pengetahuan,

ketrampilan dan

kemampuan untuk

merawat

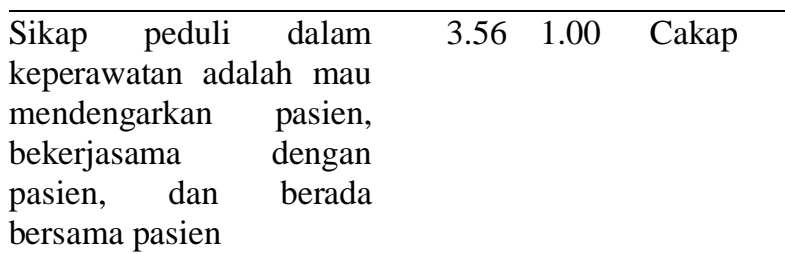

\begin{tabular}{lrlll}
\hline Perawat & perlu & 3.16 & 0.97 & Kompeten \\
menyeimbangkan & antara & & & \\
ketergantungan & dalam & & & \\
penggunaan tehnologi mesin & & & \\
$\begin{array}{l}\text { dan kemampuan } \\
\text { merawat pasien }\end{array}$ & & & & \\
\end{tabular}

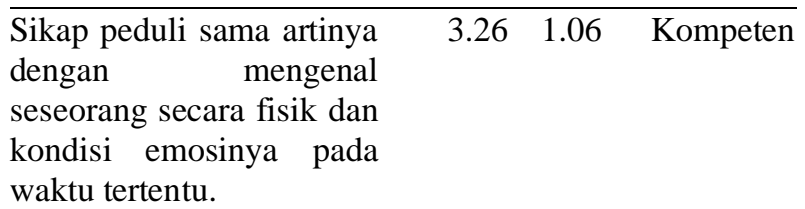

Perawat harus melibatkan $3.33 \quad 1.03 \quad$ Kompeten pasien dalam menyusun rencana keperawatan untuk menjamin

keakuratan dan kelengkapan proses perawatan pasien

\begin{tabular}{llll}
\hline Kemampuan & 3.01 & 1.08 & Kompeten \\
penggunaan & & & \\
teknologi merupakan & & & \\
keahlian & & & \\
menggunakan mesin & & & \\
dalam merawat & & & \\
pasien & & & \\
\hline
\end{tabular}




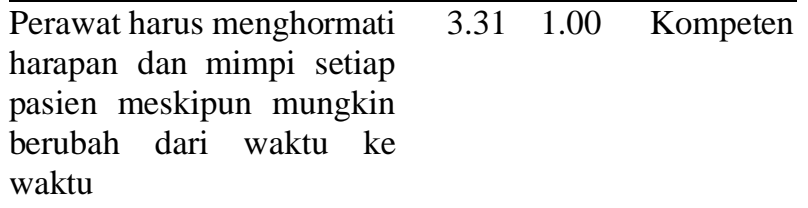

\begin{tabular}{lllll}
\hline $\begin{array}{l}\text { Perawat perlu menerapkan } \\
\text { praktik keperawatan }\end{array}$ & 3.40 & 1.07 & Kompeten \\
dengan sikap peduli dalam & & & \\
mengkaji dan & & & \\
menginterpretasikan data & & & \\
pelayanan kesehatan & & & &
\end{tabular}

\begin{tabular}{llllll}
\hline Perawat perlu menghargai & 3.41 & 1.06 & Kompeten
\end{tabular} pasien tentang

pengetahuannya terhadap diri

sendiri dan perawatan yang

diterima

\begin{tabular}{lrlll}
\hline $\begin{array}{l}\text { Perawat } \\
\text { hubungan }\end{array}$ & $\begin{array}{r}\text { menjalin } \\
\text { dengan }\end{array}$ & 3.51 & 1.01 & Cakap \\
pasiennya dalam rangka & & & \\
menciptakan suasana & & & \\
aman dan nyaman & & & &
\end{tabular}

\begin{tabular}{lclll}
\hline $\begin{array}{l}\text { Perawat } \\
\text { kompeten }\end{array}$ & yang & 3.38 & 1.02 & Kompeten \\
melaksanakan tugas & & & \\
dan mengatur emosi & & & \\
secara kreatif dalam & & & \\
memenuhi kebutuhan & & & \\
pasien & & & &
\end{tabular}

\begin{tabular}{|c|c|c|}
\hline $\begin{array}{l}\text { Memahami pasien berarti } 3.41 \\
\text { menghormati } \\
\text { tersebut sebagai individu } \\
\text { secara utuh setiap waktu }\end{array}$ & 1.06 & Kompeten \\
\hline 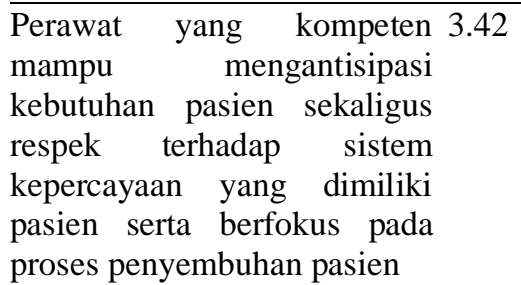 & 1.00 & Kompeten \\
\hline
\end{tabular}

\begin{tabular}{lllll}
\hline Kepedulian dalam proses 3.27 & 1.11 & Kompeten
\end{tabular} keperawatan dapat terjadi pada situasi belajar dan mengajar antara perawat, pasien dan anggota keluarga

\begin{tabular}{lllll}
\hline Kepedulian dalam merawat & 3.37 & 0.98 & Kompeten
\end{tabular} membantu mengurangi kerentanan dan berbagai stres/kecemasan yang terjadi dalam hubungan perawat dan pasien

\begin{tabular}{|c|c|c|c|}
\hline $\begin{array}{l}\text { Komitmen tanpa pamrih } \\
\text { terhadap kebutuhan, } \\
\text { harapan, dan mimpi } \\
\text { pasien adalah bentuk } \\
\text { kepedulian }\end{array}$ & 3.42 & 1.07 & Kompeten \\
\hline $\begin{array}{l}\text { Sebagai bentuk } \\
\text { kepedulian didalam } \\
\text { keperawatan, } \\
\text { kemampuan } \\
\text { menggunakan teknologi } \\
\text { dengan berbagai cara } \\
\text { untuk saling mengenal } \\
\text { sehingga perawat dan } \\
\text { pasien dapat saling } \\
\text { memahami satu dengan } \\
\text { yang lain }\end{array}$ & 3.24 & 0.96 & Kompeten \\
\hline $\begin{array}{l}\text { Perawat menggunakan } \\
\text { tehnologi dan sentuhan } \\
\text { kemanusiaan secara bersama- } \\
\text { sama dalam rangka menjalin } \\
\text { relasi dengan pasiennya } \\
\text { secara utuh dan menitik } \\
\text { beratkan pada kepedulian }\end{array}$ & 3.34 & 1.04 & Kompeten \\
\hline
\end{tabular}

Hasil penelitian menunjukan ada hubungan yang signifikan antara kemampuan menggunakan teknologi (alat-alat kesehatan/medical devices) dengan caring mahasiswa profesi $(\mathrm{p}=0.000$; $\mathrm{R}=0.630$ ).

Hasil penelitian menunjukan ada hubungan signifikan antara kemampuan menggunakan teknologi (Informasi dan Teknologi Komunikasi/Information and communication technology) dengan caring mahasiswa profesi ners ( $\mathrm{p}=0.000 ; \mathrm{R}=0.469)$.

Table 7. Hubungan antara kemampuan menggunakan teknologi keperawatan dan tingkat caring mahasiswa Profesi Ners

\section{Caring mahasiswa profesi}

\begin{tabular}{llll}
$\begin{array}{l}\text { Kemampuan } \\
\text { menggunakan } \\
\text { teknologi }\end{array}$ & $\begin{array}{l}\text { Cor.C } \\
\text { oef }\end{array}$ & P-Val & $\begin{array}{l}\text { Interpreta } \\
\text { si }\end{array}$ \\
\hline $\begin{array}{l}\text { Alat-alat } \\
\text { kesehatan } \\
\text { (medical devices) }\end{array}$ & 0.630 & 0.000 & Significant \\
$\begin{array}{l}\text { Informasi dan } \\
\text { Teknologi }\end{array}$ & & & \\
$\begin{array}{l}\text { Komunikasi } \\
\text { (Information and } \\
\text { communication } \\
\text { technology) }\end{array}$ & & 0.000 & Significant \\
\end{tabular}




\section{PEMBAHASAN}

\section{Data Demografi}

Hasil penelitian pada table 1 diatas menunjukan sebagian besar responden yaitu $90 \%$ dengan jenis kelamin perempuan. Sebagaian besar profesi sebagai perawat adalah perempuan, karena secara tradisional perempuan merawat bayinya. Peran merawat ini menjadi lebih luas yakni merawat orang sakit dan memperhatikan orang-orang yang menderita. Keperawatan sebagai sebuah tindakan cintakasih, pelayanan terhadap sesama, dan pengorbanan diri sejalan dengan ajaran gereja pada masa itu(Gould, 1950). Demikian pula halnya di Indonesia, sampai saat ini profesi perawat masih didominasi oleh kaum perempuan.

Hasil penelitian pada table 2 Datas menunjukan bahwa sebagian besar responden berada pada usia remaja akhir yaitu sebanyak $82.2 \%$. Usia Masa remaja akhir adalah rentang antara 17-25 tahun. Penggunaan teknologi sudah terintegrasi pada semua kelompok usia termasuk usia remaja akhir. Ketertarikan menggunakan teknologi berkembang sejalan dengan invoasi dalam perkembangan teknologi informasi dan komunikasi(Wu et al., 2015).

Hasil penelitian pada table 3 diatas menunjukan bahwa sebagian besar responden berasal dari program regular yaitu sebanyak $74.4 \%$. Hal ini bisa karena di Indonesia menurut permenkes 26 tahun 2019 tentang Peraturan Pelaksanaan UU 38 tahun 2018 tentang keperawatan disebutkan pada pasal 17 bahwa perawat profesi memiliki kewenangan untuk melakukan pengkajian keperawatan secara hoistik, menetapkan diagnosis keperawatan, melaksanakan tindakan keperawatan, mengevaluasi hasil tindakan keperawatan, melakukan rujukan, memberikan tindakan pada keadaan gawat darurat sesuai dengan kompetensi, memberikan konsultasi keperawatan dan berkolaborasi dengan dokter, melakukan penyuluhan kesehatan dan konseling, melakukan penatalaksanaan pemberian obat kepada klien sesuai dengan resep tenaga medis atau obat bebas dan obat bebas terbatas. Sedangankan perawat vokasi sesuai dengan pasal 23 ayat 3 disebutkan bahwa perawat vokasi memiliki wewenang terbatas yaitu melakukan pengkajian keperawatan secara holistic ditingkat individu, menjalon kemitraan dalam perawatan kesehatan masyarakat dan melakukan penyuluhan kesehatan dan konseling. Pembatasan kewenangan perawat vokasi menyebabkan peminat untuk masuk jenjang D3 keperawatan berkurang dan masyarakat lebih memilih program $\mathrm{S} 1$ keperawatan. Hal ini mendukung hasil penelitian dimana partisipan yang berasal dari program regular lebih banyak dibandingkan dengan program alih jenjang. Selain itu, jumlah perawat yang sudah lulus dari program diploma keperawatan akan melanjutkan ke jenjang sarjana keperawatan jika mendapatkan tugas belajar dari institusi tempat mereka bekerja.

\section{Kemampuan Menggunakan Tekologi Keperawatan (Medical Devices)}

Hasil penelitian menunjukan bahwa responden menyatakan diri "cakap" dalam menggunakan alat kesehatan (medical devices) dalam hal berikut: Saya mampu mengukur tekanan darah pasien dengan menggunakan tensimeter manual atau elektrik (3.67); Saya mampu menginterpretasikan hasil pemeriksaan tekanan darah pasien (3.52); Saya mampu menyimpan tensimeter dengan cara yang benar (mengembalikan air raksa pada posisi nol)(3.74); Saya mampu mengkaji suhu tubuh pasien dengan menggunakan termometer elektronik dan mengerti makna dari hasil pemeriksaan (3.79); Saya mampu menggunakan remote air condition (AC) untuk memberikan lingkungan yang nyaman pada pasien (3.70); Saya mampu mencari informasi tentang kesehatan secara online (3.51); Saya mampu memasang folley catheter pada pasien (2.98). Hasil penelitian ini menunjukan bahwa mahasiswa profesi Ners tidak asing dengan teknologi keperawatan khususnya alat-alat kesehatan seperti yang disebutkan dalam pernyataan diatas. Hal ini karena mahasiswa sudah mendapatkan pembelajaran selama masa 
akademik melalui praktik laboratorium dan juga praktik klinik di lapangan. Hal ini tentunya persiapan bagi mahasiswa profesi ners untuk memasuki dunia kerja, karena alat-alat kesehatan tersebut digunakan oleh perawat saat mereka berdinas. Setiap hari perawat menggunakan berbagai alat elektronik dalam merawat pasien seperti tensimeter, timbangan, glukotest, alat untuk mengukur pemasukan kalori, tingkat aktivitas, pola tidur, dll. Semuanya ini membantu perawat dalam memperoleh informasi tentang pasien yang dirawatnya dan membantu mereka dalam memberikan perawatan yang tepat. Digital Nursing Technology (DNT) diperlukan untuk membantu tindakan keperawtan yang cepat (seperti dalam guidline pengambilan keputusan), mengurangi kehadiranlangsung perawatan, menghadirkan pengganti perawat seperti robot (Krick et al., 2020). Sebaliknya hasil penelitian menunjukan responden menyatakan diri masih "pemula" dalam hal: Saya mengetahui bahwa teknologi termasuk pengelolaan alat tenun (mean 2.18); Saya mampu menggunakan wireless sebagai sarana komunikasi dengan tim medis yang lain (mean 2.33); dan Saya mampu mengobservasi pasien yang menggunakan tracheostomy, stoma, dll (mean 2.49). Hal ini dapat disebabkan karena mahasiswa kurang terpapar dengan situasi diatas sehingga pemahaman dan ketrampilan dalam menggunakan teknologi tersebut masih membutuhkan bimbingan melalui demonstrasi dan penjelasan. Seperti hal nya mahasiswa profesi ners dalam hal ini perlu penjelasan konsep tentang linen di rumah sakit. Linen adalah istilah untuk menyebutkan seluruh produk tekstil yang berada di rumah sakit yang meliputi linen di ruang perawatan maupun baju bedah diruang operasi (OK). Ada linen kotor dan ada linen terinfeksi. Pengumpulan linen ini harus dipisahkan dengan kantung yang dibedakan warnanya. Demikian juga temperatur untuk mencuci adalah $65^{\circ} \mathrm{C}$ selama 10 menit atau $71^{\circ} \mathrm{C}$ selama 3 menit (GABUR, 2018). Demikian juga halnya penggunaan wireless sebagai sarana komunikasi dengan tim medis dan perawatan pasien yang menggunakan tracheostomy serta stoma frekuensi penggunaannya masih kurang.

\section{Kemampuan Menggunakan Informasi dan Teknologi Komunikasi (ITK)}

Hasil penelitian menunjukan bahwa responden menyatakan diri "cakap" dalam menggunakan informasi dan teknologi komunikasi berdasarkan pernyataan berikut: Saya mampu menggunakan email sebagai sarana komunikasi (mean 3.62); Saya mampu mengakses internet dan world wide web (3.51). Cakap artinya mampu menggunakan dan mengerti penggunaan teknologi secara keseluruhan, mengerti situasi secara keseluruhan dan mengenal tujuan, belajar dari pengalaman bagaimana mengatasi masalah dengan menggunakan teknologi, mampu membaca hasil dari alat/teknologi yang digunakan, serta mampu membaca situasi dan membuat keputusan penggunaaan alat/teknologi (Yuliati, Ssps and Lorica, 2005).

Information and communication technologies (ICTs) atau informasi dan teknologi komunikasi (ITK) merupakan semua teknologi yang termasuk dalam media elektronik yang berfungsi untuk mendokumentasikan, menyimpan, memproses dan media pertukaran informasi dalam rangka meningkatkan kesehatan, mencegah penyakit, mengobati penyakit dan menangani pernyakit kronik, dan seterusnya. Manfaat penggunaan teknologi informasi dan komunikasi dalam dunia kesehatan sudah diketahui dengan baik oleh masyarakat, termasuk oleh mahasiswa keperawatan. Kemampuan perawat dalam menggunakan ITK mempengaruhi pelayanan yang diberikan oleh perawat(Rouleau, Gagnon and Côté, 2015). Penggunaan teknologi informasi dan komunikasi berupa email dan internet adalah media yang sangat dekat dengan mahasiswa keperawatan. Mahasiswa menggunakan kedua media tersebut hampir setiap hari dalam kehidupan mereka untuk mencari informasi yang berkaitan dengan informasi kesehatan yang menjadi bagian 
dari profesi mereka.

Hasil dari penelitian menunjukan bahwa tidak ada responden yang dalam penggunaan informasi dan teknologi komunikasi tahap "trainee". Hal ini menunjukan bahwa mahasiswa profesi tidak ada yang belum punya pengalaman menggunakan teknologi tertentu, tidak percaya diri dalam menggunakan teknologi secara benar, tidak membutuhkan bimbingan dengan demonstrasi dan penjelasan verbal, tidak mampu menggunakan alat secara fleksibel, tidak tergolong baru dalam bidang praktik.

\section{Caring Mahasiswa Profesi Ners}

Hasil penelitian menunjukan responden menyatakan memiliki tingkat caring "cakap" pada pernyataan berikut: Keperawatan adalah bidang unik dari ilmu pengetahuan ketrampilan dan kemampuan untuk merawat (3.52); Sikap peduli dalam keperawatan adalah mau mendengarkan pasien, bekerjasama dengan pasien, dan berada bersama pasien (3.56); Perawat menjalin hubungan dengan pasiennya dalam rangka menciptakan suasana aman dan nyaman (3.51). Mahasiswa profesi ners menjadi cakap dalam memberikan asuhan keperawatan karena mahasiswa sudah mendapatkan pelajaran tentang caring sehingga mereka dapat menerapkan, memahami dan menjadikan caring sebagai hal utama dalam merawat pasien.

Menurut Watson, caring adalah hal penting dalam keperawatan, caring adalah inti dari pendidikan keperawatan. Caring sebagai inti dalam kurikulum pendidikan keperawatan bertujuan untuk memberikan mahasiswa pemahaman tentang konsep caring secara keseluruhan sehingga mereka dapat merawat individu secara professional. Mereka harus dapat memberikan suasana yang mendukung perasaan nyaman pasien (Zamanzadeh et al., 2014). Dijenjang akademik mahasiswa profesi Ners telah mendapatkan mata kuliah yang membahas konsep caring menurut beberapa teori keperawatan. Menurut Leinenger perilaku caring mencangkup kenyamanan, belaskasihan, kemauan, koping, empati, kesiapsediaan, bantuan, cinta, nutrisi, penguatan, perlindungan, dan perilau yang memberi inspirasi, kepekaan dan kepercayaan. Menurut Watson, perilaku caring adalah mendengarkan, kontak mata, tanggungjawab, kejujuran, sentuhan, kepekaan, memberi informasi, mampu terbuka mengungkapkan perasaan, menghargai. Sedangkan Swanson menegaskan lima (5) kunci dari caring adalah menghargai individu, ada bersama, melakukan sesuatu untuk individu, memampukan, dan membantu meningkatkan iman (Gözütok Konuk and Tanyer, 2019). Sebelum menjadi perawat professional, mahasiswa harus dibekali sejak masa kuliah tentang perilaku dan tanggungjawab caring. Oleh karena itu pendidik memperhatikan dan mempersiapkan dengan sunguh pengalaman klinik bagi mahasiswa menerpakan tentang caring (Kobe, Downing and Poggenpoel, 2020).

Praktik klinik hal penting dari pendidikan keperawatan, karena pada saat praktik mahasiswa diperkenalkan dengan profesi perawat yang sesungguhnya. Menurut Nash et all (2010) kesempatan yang maksimal bagi mahasiswa untuk belajar adalah dengan memberikan mahasiswa kesempatan mengalami kehidupan sesungguhnya dalam pekerjaan perawat. Belajar dari pengalaman akan memberikan pelajarn dan persepsi yang utuh tentang pengalaman, persepsi, pengetahuan, dan perilaku (Temane et al., 2016).

\section{Hubungan antara kemampuan menggunakan teknologi keperawatan dan tingkat caring mahasiswa Profesi Ners.}

Hasil penelitian menunjukan ada hubungan yang signifikan antara kemampuan menggunakan teknologi (alat-alat kesehatan/medical devices) dengan caring mahasiswa profesi Ners $(\mathrm{p}$ $=0.000 ; \mathrm{r}=0.630$. Ada hubungan signifikan antara kemampuan menggunakan teknologi (Informasi dan Teknologi Komunikasi/Information and communication technology) dengan caring mahasiswa profesi ners $(\mathrm{p}=0.000$; $\mathrm{r}=0.469$ ). Kemampuan menggunakan 
teknologi membuat perawat memahami pasien sebagai manusia yang utuh atau holistik (Koszalinski, and Locsin, 2015). Jika perawat memahami pasien secara utuh maka dia akan memahami segala aspek dalam diri pasien sebagai pribadi yang unik, hal ini akan membantu pasien untuk berkembang dan mempercepat proses penyembuhan. Kemampuan perawat menggunakan teknologi adalah adalah ekspresi caring dalam keperawatan, yang mana caring dan teknologi sebagai satu kesatuan. Memberikan caring pada pasien membutuhkan kehadiran perawat dan pasien, perlu adanya relasi antara perawat dan pasien atau yang membutuhkan. Teknologi memegang peranan penting dalam perawatan kesehatan, teknologi memegang peranan penting dalam perawatan pasien kritis, teknologi digunakan untuk meningkatkan keamanan pasien, menyelamatkan jiwa pasein dan membatu perawat alam pekerjaannya. Pada jaman ini majunya ilmu pengetahuan dan teknologi secara pesat, tenaga kesehatan professional harus mendapatkan edukasi tidak hanya soal kecakapan menggunakan teknologi tetapi juga ketulusan caring kepada pasien. Menanamkan caring sejak masa pendidikan sangat penting karena ini adalah tahap pertama mahasiswa belajar nilai dan makna dari profesi perawat. Kurikulum yang memberikan perhatian dan penekanan pada konsep caring dan juga adanya role model atau teladan penerapan caring oleh dosen, tenaga kependidikan, preceptor klinik, dan staff medis adalah hal penting dalam meningkatkan caring atau kepedulian mahasiswa profesi ners (Ma et al., 2014). Teladan tenaga pendidik dan clinical instructors atau pembimbing didasari oleh motivasi cinta dan belaskasihan serta tanggungjawab dan hal ini dicontoh oleh mahasiswa keperawatan (Honkavuo, 2019).

\section{KESIMPULAN}

Ada hubungan yang signifikan antara kemampuan menggunakan teknologi (alatalat kesehatan/medical devices) dengan caring mahasiswa profesi Ners $(\mathrm{p}=0.000 ; \mathrm{r}=$
0.630. Ada hubungan signifikan antara kemampuan menggunakan teknologi (Informasi dan Teknologi Komunikasi/Information and communication technology) dengan caring mahasiswa profesi ners $(\mathrm{p}=0.000 ; \mathrm{r}=0.469)$. Kemampuan menggunakan teknologi membuat perawat memahami pasien sebagai manusia yang utuh atau holistic. Jika perawat memahami pasien secara utuh maka dia akan memahami segala aspek dalam diri pasien sebagai pribadi yang unik, hal ini akan membantu pasien untuk berkembang dan mempercepat proses penyembuhan. Kemampuan perawat menggunakan teknologi adalah adalah ekspresi caring dalam keperawatan, yang mana caring dan teknologi sebagai satu kesatuan. Teknologi memegang peranan penting dalam perawatan kesehatan, teknologi digunakan untuk meningkatkan keamanan pasien, menyelamatkan jiwa pasien dan membatu perawat dalam pekerjaannya. Menanamkan caring sejak masa pendidikan sangat penting karena ini adalah tahap pertama mahasiswa belajar nilai dan makna dari profesi perawat.

\section{DAFTAR PUSTAKA}

Abbott, M. B. and Shaw, P. (2016) 'Virtual nursing avatars: Nurse roles and evolving concepts of care', Online Journal of Issues in Nursing, 21(3), pp. 1-7. doi: 10.3912/OJIN.Vol21No03PPT39,05.

Blum, C. A. (2010) 'Teaching Caring Nursing to RN-BSN Students Using Simulation Technology', International Journal of Human Caring, 14(2), pp. 40-49. doi: 10.20467/1091-5710.14.2.40.

Dean,, Patrick J., RN, MSN, EdD, O. (2016) 'Nursing Considerations for an Emerging and Enlarging Symbiosis Between Technology and Integrative Human Health: Need for a Systematized Base for Caring Science', International Journal for Huan caring, 20(4).

Doswell, W. M. et al. (2013) 'mHealth: Technology for nursing practice, education, and research', Journal of Nursing Education and Practice, 3(10). doi: 10.5430/jnep.v3n10p99.
GABUR, I. (2018) GAMBARAN PENGELOLAAN LINEN RUMAH SAKIT UMUMPUSAT SANGLAH DENPASAR 
TAHUN 2018. Denpasar. Available at: http://repository.poltekkes-

denpasar.ac.id/338/.

Gould, M. E. (1950) 'History of Nursing', The Lancet, 255(6613), p. 1018. doi: 10.1016/S0140-6736(50)90850-6.

Gözütok Konuk, T. and Tanyer, D. (2019) 'Investigation of Nursing Students' Perception of Caring Behaviors', Journal of Caring Sciences, 8(4), pp. 191-197. doi: 10.15171/jcs.2019.027.

Hidayat, A. A. A. (2017) Metodologi Penelitian Keperawatan dan Kesehatan. Jakarta: Salemba Medika.

Honkavuo, L. (2019) 'Educating Nursing Students - Emotional Intelligence and the Didactics of Caring Science.', International Journal of Caring Sciences, 12(1), pp. 1-10. Available at: http://0search.ebscohost.com.serlib0.essex.ac.uk/lo gin. aspx? direct=true $\& d b=c c m \& A N=13669$ $8165 \&$ site $=$ eds-live.

Kobe, S. C., Downing, C. and Poggenpoel, M. (2020) 'Final-year student nurses' experiences of caring for patients', Curationis, 43(1), pp. 1-10. doi: 10.4102/curationis.v43i1.2033.

Koszalinski, R. S. and Locsin, R. C. (2015) 'Persons who Dependent Upon Technologies for Care: Lived Experience of Being Cared for Following Lower Limb Amputation', International Journal of Human Caring, 19(4), pp. 38-43. doi: 10.20467/1091-5710.19.4.38.

Krick, T. et al. (2020) 'Measuring the effectiveness of digital nursing technologies: Development of a comprehensive digital nursing technology outcome framework based on a scoping review', BMC Health Services Research. BMC Health Services Research, 20(1), pp. 1-18. doi: 10.1186/s12913-020-05106-8.

Kusmiran (2015) 'Soft Skill Caring dalam Pelayanan Keperawatan.', in. Jakarta: Trans Info Media.

Locsin, R. C. (2016) 'Technological Competency as Caring in Nursing: Co-creating Moments in Nursing Occuring Within the Universal Technological Domain', J Theory Constr Test.
Ma, F. et al. (2014) 'Baccalaureate nursing Students' perspectives on learning about caring in China: A qualitative descriptive study', BMC Medical Education. BMC Medical Education, 14(1), pp. 1-9. doi: 10.1186/1472-6920-14-42.

Nursalam (2017) Metodologi Penelitian Ilmu Keperawatan Pendekatan Praktis. Jakarta: Salemba Medika.

Oberty Elvi (2016) 'Efektifitas dalam penerapan teknologi pda (', (983).

Oktariana, V. D. (2014) 'Situasi dan Analisis Glaukoma.pdf', Kementerian Kesehatan RI Pusat Data dan Informasi.

Rahayu (2015) Metodologi Penelitian Kesehatan Masyarakat. Yogyakarta: Deepublish.

Rouleau, G., Gagnon, M. P. and Côté, J. (2015) 'Impacts of information and communication technologies on nursing care: An overview of systematic reviews (protocol)', Systematic Reviews. ???, 4(1), pp. 1-9. doi: 10.1186/s13643-015-0062-y.

Saryono (2018) Metodologi Penelitian Kesehatan. Yogyakarta: Mitra Cendikia. Yogyakara: Mitra Cendikia.

'TECHNOLOGY IN NURSING CARE AND WORKLOAD IN AN ICU' (no date) J Nurs UFPE on line., Recife, 10(Suppl. 2):903-7, Feb., 2016.

Temane, A. et al. (2016) 'Lived experiences of student nurses caring for intellectually disabled people in a public psychiatric institution', Curationis, 39(1), p. 1601. doi: 10.4102/curationis.v39i1.1601.

De Veer, A. J. E. et al. (2011) 'Successful implementation of new technologies in nursing care: A questionnaire survey of nurse-users', BMC Medical Informatics and Decision Making. BioMed Central Ltd, 11(1), p. 67. doi: 10.1186/1472-6947-11-67.

Wicaksono. (2012) 'Kiat Keperawatan (Caring) Dalam meningkatkan Mutu Asuhan Keperawatan', Jurnal Keperawatan, 5. Available at: https://doi.org/02-121.

$\mathrm{Wu}, \mathrm{Y}$. H. et al. (2015) 'Bridging the digital divide in older adults: A study from an initiative to inform older adults about new technologies', Clinical Interventions in 
Aging, 10, pp. 193-201. doi: 10.2147/CIA.S72399.

Yuliati, I., Kusumaningsih, I. and Novita, R. V. F. (2017) 'FACTORS AFFECTING INDONESIAN STUDENT NURSES' CARING BEHAVIOR', in 3 rd International Reserch Conference.

Yuliati, I., Ssps, S. and Lorica, J. D. (2005) 'AN INSTRUMENT DEVELOPMENT AND VALIDATION OF THE TECHNOLOGICAL SKILL COMPETENCY IN NURSING ( TSCNI ) Catholic School of Health Sciences St . Vincentius a Paulo Surabaya 60241, Indonesia St . Paul University Philippines ( SPUP ), Mabini Street, Tuguegarao', pp. 16.

Yuliati I, L. J. (2018) 'An Intrument Development and Validation of The Technological Skill Competency in Nursing (TSCNI).', in 4th SPUP International Health Congress.

Zamanzadeh, V. et al. (2014) 'First and FourthYear Student's Perceptions about Importance of Nursing Care Behaviors: Socialization toward Caring.', Journal of caring sciences, 3(2), pp. 93-101. doi: $10.5681 /$ jcs.2014.010. 